\section{Abstractions}

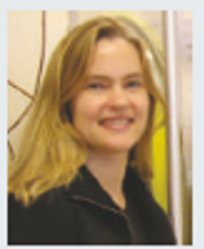

\section{SENIOR AUTHOR}

Proteins that contain metals - metalloproteins - often catalyse complicated or unusual chemical reactions. For example, the protein SyrB2 uses iron to catalyse the formation of a carbon-chlorine bond, thereby adding a chlorine atom to the amino acid threonine. To understand this reaction, Cathy Drennan, associate professor of chemistry at the Massachusetts Institute of Technology (MIT), and her group solved the crystal structure of SyrB2. Published on page 368, the structure reveals an iron-binding motif that differs from related enzymes in having an additional site for a chlorine atom to bind directly to iron. This helps to explain how the enzyme adds the chlorine atom. In her work, Drennan draws on lessons in perseverance, perspective and patience that shelearned when she took a breakbetween her undergraduate and PhD degrees to teach in aQuaker boarding school in lowa.

What did you learn from that experience? Ilearned so much aboutmyself. It was a small school of 60 students. I lived in the girls' dorm and taught chemistry, physics, drama - a wide range of things. And the students were really honest. We had Quaker kids; kids that had been kicked out of school in Chicago; kids that were justout of drug rehab. After that, when I have grant deadlines, I remember whata real crisis is.

How else did those experiences translate into running a lab?

Ilearned alot about running my research groups, and how to res olve conflicts. I've also learned about the 'diamond in the rough'. All the MIT students are reallygood. But the lowa kids showed me what amazing things people can do when given the chance.

How did teaching different high-school subjects affect your university teaching? Those three years of boot camp - when you're giving lectures almost every hour mademe a more dynamic, energetic lecturer. It alsohelps with my presentations. As a junior professor, I've had togive plenty of talks.

What's the biggest lesson you leamed about research from teaching?

In life not everything is going to work out - the trick is to celebrate the things that do. It's easy when things go well, but the measure of aperson and scientist is how they handle themselves when things don't. There are so many ups and downs in research;you mightbe working on a structure and an other group comes out with the same paper before you do. I tell my students that nothing worked quickly for me in grad schoolor my postdoc. Everything was hard and slow, but the results were worth it.
MAKING THE PAPER

Sunney Xie

Four years' hard labour earneda

picture of gene activity in single cells.

Sunney Xie's identical twin daughters have the same set of genes but different personalities. Why? The question has intrigued their father since the girls' birth six years ago. Now, a study reported on page 358 of this issue showing how genes are activated in cells may bring him a little closer to an answer.

Up to this point, scientists have studied gene expression in many cells at once. The ability to home in on a protein molecule being manufactured in a single cell would not only offer a more accurate view of the process but could help scientists understand how the same genes produce different phenotypes. This possibility prompted Xie's lab at Harvard University to embark on a project that took four years to complete.

During a lab meeting, Xie proposed the idea of using $\beta$-galactosidase, a bacterial enzyme, to monitor the expression of a single protein in a living cell. The enzyme is routinely used as a reporter in gene-expression studies, because a single molecule of protein generates many fluorescent compounds (fluorophores), creating a detectable signal. Xiés lab had already started using the enzyme to study gene expression in vitro, but lab members were wary of going into living cells. One problem was that the fluorophores quickly ooze out of the cell, making measurements in vivo difficult. In addition, no one in Xie's lab had expertise in molecularbiology techniques. "Most people thought it would not work," says Xie.

In the end, a first-year graduate student, Long Cai, took the plunge. He was later joined on the project by postdoc Nir Friedman, with whom he shares first authorship of the Nature paper.

Xie also recruited a molecular biologist to the team. "I interviewed half a dozen candidates and they all turned me down," he laughs. "They looked around the lab and got

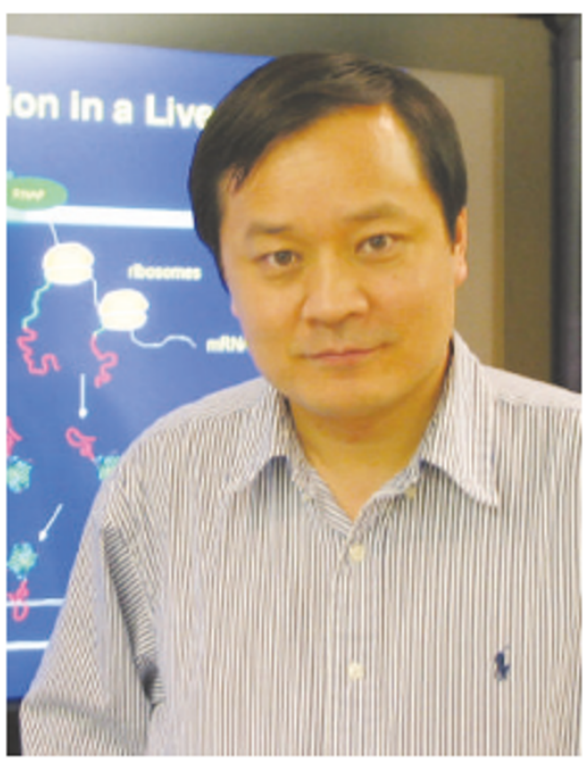

scared." Finally, Jie Xiao accepted his offer and trained half of Xie's group on molecularbiology techniques.

The team tried different strategies to measure $\beta$-galactosidase expression, but initially nothing panned out. "Every time we thought we got the system to work, it turned out to be an artefact," says Xie. Two years into the project, Cai and Friedman decided to give microfluidics, tiny devices that hold nanolitres of liquid, a try. They placed individual cells in microfluidic chambers to trap the fluorophores. The signal in each chamber was then measured in real-time using a fluorescence microscope.

Using this system, Xie and his colleagues determined that protein expression occurs in short, randomly timed bursts in each cell. The number of protein molecules made during each burst follows an exponential distribution. In addition to providing footage of gene expression, the technique opens the door to monitoring many genes - one gene and one cell at a time - in response to different stimuli. "I knew this was going to be a significant experiment," says Xie. "Although, I guess I could not articulate why as well as I can now."

\title{
QUANTIFIED PODCASTS
}

\section{A numerical pers pective on Nature authors.}

The Nature podcast, a free audio show featuring highlights from the current issue, goes online each week. Chris Smith, a virologist and radio presenter from the University of Cambridge presents the show. It includes discussions on topical issues with Nature journalists, and short interviews in which the authors of Nature papers explain the significance of their work and talk about what drew their attention to the problem, how experiments were carried out and what they have learned for the future.

This week, four authors discuss their research on the Nature podcast, covering a variety of topics from folding DNA (see page 297) to firefly lights (see page 372).

Youcan download the Nature podcast at www.nature.com/nature/podcast.
24 Nature podcasts have been published since their launch in September 2005.

4 is the average number of papers featured ineach Nature podcast.

23 minutes is the average length of a Nature podcast show.

63 is the percentage of authors interviewed about their work in Nature podcasts so far that have beentalking aboutpapers in the biological sciences. 